\title{
Differences of terrestrial mammal species diversity between natural forest and edge forest areas in Batutegi Protected Forest, Lampung, Indonesia
}

\author{
Robithotul Huda ${ }^{1,2}$, Yossa Istiadi ${ }^{1}$ and Dolly Priatna ${ }^{1}$ \\ ${ }^{1}$ Graduate School of Environmental Management, Pakuan University, Jl. Pakuan Kotak Pos 452, Bogor 16129, Indonesia \\ ${ }^{2}$ International Animal Rescue Indonesia Foundation, Jl. Curug Nangka, Tamansari, Bogor 16610, Indonesia
}

Corresponding author: Robithotul Huda, E-mail: robihuda@gmail.com

\begin{abstract}
This research is an explorative quantitative survey by testing differences in species of terrestrial mammals found in natural forest (core) and edge forest (ecoton) areas. The data collection was obtained by using camera traps installed for 3 months based on a grid cell $2 \times 2$ $\mathrm{km}$, with a total of 16 camera traps placed in core area and another 17 were in ecotone. The object of this research was medium $(>0.3$ $\mathrm{kg}$ ) to large terrestrial mammals. The $\mathrm{t}$ test was used to determine the differences the species diversity of mammals between two research areas. The study shows that there are 22 species of terrestrial mammals with a total of 552 individuals, which is distributed in both research areas. In the core area there are 18 species with 237 individuals, while in the ecotone there are 18 species with 315 individuals. Analyses the species richness index was 17.8171 for the core area while 17.8262 for the ecotone area. Similarity index in both study areas ranged from 0.7106 to 1 . While the value of diversity index (Shannon-Wiener) in the core area $\mathrm{H}^{\prime}=2.2038$ and in the ecotone area $\mathrm{H}^{\prime}=2.0541$. Three species with the greatest relative abundance values are Porcupine (Hystrix brachyura), Barking Deer (Muntiacus muntjak), and Wild Boar (Sus scrofa). Based on the t tests of the two research areas, which are core area and ecotone, obtained $\mathrm{t}_{\text {count }}$ 0.41365 ( $<<0.05$ ), it can be interpreted that the diversity of terrestrial mammals species in the core and ecotone areas is not the same.
\end{abstract}

\begin{abstract}
ABSTRAK
Penelitian ini merupakan penelitian kuantitatif survei eksploratif dengan melakukan pengujian perbedaan terhadap jenis mamalia teresterial yang ditemukan di wilayah hutan alam (inti) dan wilayah hutan tepi (ekoton). Pendataan mamalia teresterial menggunakan camera trap yang dipasang selama 3 bulan berdasarkan grid cell 2 x 2 km, dengan 16 camera trap dipasang di areal inti dan 17 lainnya di ekoton. Objek penelitian adalah mamalia teresterial berukuran sedang $(>0,3 \mathrm{~kg})$ hingga mamalia besar. Uji t digunakan untuk menentukan perbadaan keragaman jenis mamalia teresterial pada dua areal penelitian. Hasil penelitian menunjukkan terdapat 22 jenis mamalia teresterial dengan total 552 individu, yang tersebar di kedua areal penelitian. Pada areal inti terdapat 18 jenis dengan 237 individu, sedangkan pada areal ekoton ditemukan 18 jenis dengan 315 individu. Analisis indeks kekayaaan jenis menunjukkan nilai 17,817 untuk areal inti dan 17,8262 untuk areal ekoton. Indeks kemerataan pada kedua areal penelitian berkisar antara 0,7106 hingga 1. Sedangkan nilai indeks keragaman (Shannon-Wiener) pada areal inti $H^{\prime}=2,2038$ dan pada areal ekoton $H^{\prime}=2,0541$. Tiga jenis mamalia teresterial dengan kelimpahan relatif terbesar yaitu Landak (Hystrix brachyura), Kijang (Muntiacus muntjak), dan Babi hutan (Sus scrofa). Berdasarkan uji beda terhadap dua areal penelitian yaitu areal hutan alam (areal inti) dan areal tepi hutan (ekoton) didapatkan $\mathrm{t}_{\text {hitung }} 0,41365(\mathrm{p}<0,05)$, maka dapat diartikan bahwa keragaman jenis mamalia teresterial di areal inti dan ekoton tidak sama.
\end{abstract}

Keywords: Terrestrial mammals, diversity, natural forest, ecotone, Batutegi, Lampung

\section{INTRODUGTION}

Indonesia is home to around 720 species of mammals or more than $13 \%$ of the world's mammals, whilst 275 species of mammals found in the main island of Sumatra (Widjaya et al., 2011). Sumatra's geographical location which is located in Sunda shelf has created the uniqueness of mammal

Submitted 30 July 2019; Accepted 30 March 2020 species diversity on this island, and different from other places in Indonesia. Varying in ecosystem types and large size of the island resulting in a unique zoogeographic distribution pattern (Whitten et al., 2000), thus it is placing the island in second order in the diversity of mammal species after Kalimantan Island (Widjaja et al., 2011). 
As a habitat for mammals, the forest provides a very important role. However, not all forest habitats are suitable for certain types of mammals due to diverse forest habitat conditions (Alikodra, 2002). The types of mammals found in primary forests will be different from disturbed forests because there are differences in the structure of vegetation. Vegetation structure is an important biotic component in a habitat as it plays a role in the movement and distribution of mammals (Kartono, et al., 2009). The diversity of habitat types and quality of a habitat will affect the number and type of mammals in an area (Kasayev et al., 2018). Some species of living mammals are limited to areas that are still in good condition and depend on highly variable habitat features so that the sensitivity and response arising from environmental changes also varies (Kartono, 2015).

Changes in forest landscape has affected terrestrial mammal species. Forest interior mammals need special resources to support their survival, while generalist mammals will be able to adapt to changes that occur within their habitat (Prasetyo, 2017). Alikodra (2010) stated that the management of forest areas is related to wildlife conservation and the determination of the status of forest areas is one of these management strategies. However, the efforts in wildlife management cover broad and complex aspects. The insistence of human activities on forest areas makes forest areas increasingly narrowed and fragmented. In a forest landscape that is fragmented by human activity, the periphery is one of the habitats favored by generalist species while forest specialist species will migrate into the core area of the forest to obtain life support resources. The explosion of mammal populations in the periphery can be a threat of conflict between human and wildlife, while populations that are concentrated in the core of the forest and unable to move to other locations will encourage the local extinction of the species.

An important and interesting community character to be studied more deeply both in concept and application is species diversity (Dharmawan et al., 2005). Diversity is a stability indicator of an ecosystem. If the diversity of an ecosystem is high, then the condition of that ecosystem tends to be stable.

The objective of this study is to identify the species of terrestrial mammals that inhabitant to natural forest area (core area) and in the forest edge area (ecotone), as well as to determine the distribution of specialist and generalist species of terrestrial mammals in Batutegi Protected Forest in Lampung Province, Indonesia.

\section{METHODS}

\section{Research location}

The study was conducted in the core block $(+10,000 \mathrm{ha})$ of the Batutegi Protected Forest, Lampung Province, Sumatra. Geographically this area is located at the coordinates of $104^{\circ} 27^{\prime}-104^{\circ}$ 54' East and $05^{\circ} 05^{\prime}-05^{\circ} 22^{\prime}$ South (Figure 1). Administratively, this area is included into four regencies i.e. Tanggamus, West Lampung, Central Lampung, and Pringsewu.

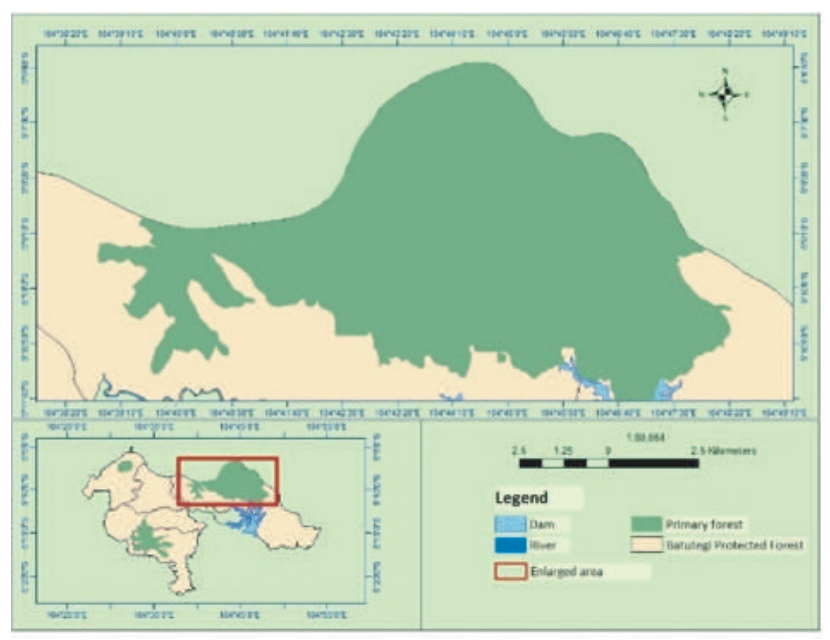

Figure 1. Location of the study area within natural forest (core area) and forest edge (ecotone) in Batutegi Protected Forest, Lampung, Sumatra, Indonesia.

This protected forest area in general has experienced changes in land use. Most of it has been turned into plantation land, but around $17.4 \%$ of the total area is still natural forest (KPHL Batutegi, 2016). In the natural forest area, there is still abundant of natural vegetation such as Shorea sp., Lithocarpus sp., and Schima wallichii. In this area can also be found many important species of animals such as 13 species of carnivorous mammals, including Sumatran Tiger (Panthera tigris), Asiatic Golden Cat (Catopuma temminckii), Malayan Sun Bear (Helarctos malayanus) and Banded Linsang (Prionodon linsang). In addition, it can easily find several species of primates such as Siamang Gibbon (Symphalangus syndactylus), Pig-tailed Macaque (Macaca nemestrina), Long-tailed Macaque 
(Macaca fascicularis), Sumatran Surili (Presbytis melalophos), Lutung (Trachypithecus cristatus), Slow Loris (Nycticebus coucang coucang) (Shancez et al., 2010; Huda et al., 2018).

\section{Data collection}

The object of this research is medium to large with weights of $0.3 \mathrm{~kg}$ and above (Ariyanto, 2007). 33 camera traps which are placed based on grid cells of $2 \times 2 \mathrm{~km}$, were employed to support in data collection. 16 camera traps installed in natural forest area (core area) while another 17 camera traps installed in forest edge area (ecotone) for three months period in April-June 2019 (Figure 2).

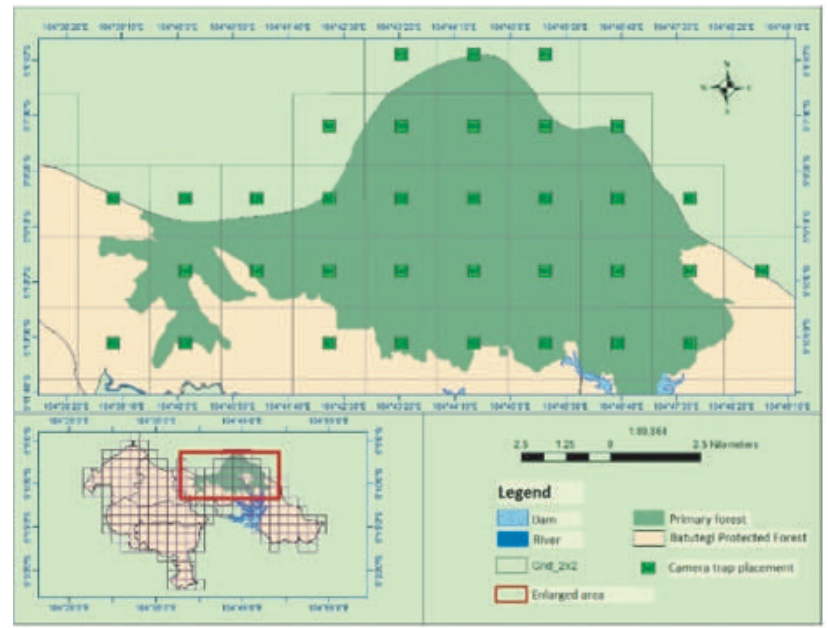

Figure 2. Placement of 33 camera traps during the study in core and ecotone areas in Batutegi Protected Forest, Lampung, Sumatra, Indonesia.

\section{Data Analysis}

Data from the trapping camera results were analyzed using fim Software, then they were calculated using several parameters of diversity such as species richness, similarity, dominance, diversity index and abundance (Magurran, 2004). T-test was used to compare the two results obtained from core area and ecotone.

Species richness in a habitat can be determined by using the Margalef Richness Index (Santosa, 1995) is as follows:

$$
\mathrm{R}=\frac{(\mathrm{S}-1)}{(\operatorname{Ln}(\mathrm{NO}))}
$$

Note:

$\mathrm{R}=$ index of species richness; $\mathrm{S}=$ total number of species in a habitat (species per habitat); $\mathrm{NO}=$ number of individuals in a habitat (individuals per habitat).
Similarity index uses the formula from Hill (Santosa, 1995) below:

$$
\mathrm{E}=1 / \mathrm{Si} \frac{1 / S i}{e H^{\prime}}
$$

Note:

$\mathrm{E}=$ index of similarity; $\mathrm{H}^{\prime}=$ Shannon index of diversity;

$\mathrm{Si}=$ Simpson Indix of diversity

The Shannon-Wiener Index $\left(\mathrm{H}^{\prime}\right)$ is calculated by a modified formula from Magurran (2004) is as follow:

$$
\mathrm{H}^{\prime}=-\Sigma \mathrm{s}(\text { pi ln pi) where pi }=\mathrm{ni} / \mathrm{N}
$$

Note:

$\mathrm{H}^{\prime}=$ Shannon-Wiener index; $\mathrm{ni}=$ number of individuals of each species; $\mathrm{N}=$ number of individuals of all species where pi is the proportion of the number of photographs in the species until-i divided by the total of all photographs

Species dominance index is calculated using the Simpson dominance index (Odum, 1983) below:

$$
\mathrm{C}=\sum(\mathrm{Pi}) 2
$$

Note:

$\mathrm{C}=$ Dominance index

$\mathrm{Pi}=(\mathrm{ni} / \mathrm{N}) \mathrm{ni}=$ proportion of a species in a community;

$\mathrm{N}=$ number of all species

Relative abundance index is calculated through below formula:

$$
\mathrm{RAI}=\frac{n i}{\sum T \mathcal{N}} \times 100
$$

Note:

RAI = Relative abundance index (/100 trap nights);

$\mathrm{ni}=$ number of independent picture of the species to-i;

$\Sigma T N=$ number of nights of camera active.

\section{RESULTS}

There were 33 camera traps that had been installed in the field during the study. However, there were only 28 cameras working properly, while the other 5 cameras were damaged and did not get any pictures. All camera traps placed for three months period with a total trapping effort of 2,259 trap nights with obtaining 4,101 individuals and there were 1,434 pictures of terrestrial mammals. Then based on the results of grouping using Jim Software programme (Sanderson and Harris, 2013), a 1,669 independent photographs (552 terrestrial mammal photographs) were obtained, with assumption that independent photograph of each species at each location is along 60 minutes. 
Based on unequal test towards two study areas of ecotone and core areas, then $t_{\text {count }}$ was obtained of 0.41365 ( $\mathrm{p}<0.05$ ). Thus, H0 is rejected and it can be interpreted that the diversity of terrestrial mammal species in the ecotone and core areas is not the same.

Calculation of richness index in each areas is obtained where in ecotone at 17.8262 and core area at 17.8171. Diversity index (Shannon-Wiener Index) $\mathrm{H}^{\prime}=2.2038$ for the core area and $\mathrm{H}^{\prime}=2.0541$ for the ecotone area. The values of similarity index is 0.7106 for the ecotone while for the core area is 0.7625 . Dominance index value for ecotone is 0.1758 and for the core area is 0.1719 (Table 1).

Table 1. Indexes of Richness, diversity, similarity, and dominance in core area and ecotone at the study area in Batutegi Protected Forest.

\begin{tabular}{|l|c|c|}
\hline \multirow{2}{*}{ Index } & \multicolumn{2}{|c|}{ Type of habitat } \\
\cline { 2 - 3 } & Natural forest & Edge forest \\
\hline Richness & 17.8171 & 17.8262 \\
\hline Diversity & 2.2038 & 2.0541 \\
\hline Similarity & 0.7625 & 0.7106 \\
\hline Dominance & 0.1719 & 0.1758 \\
\hline
\end{tabular}

Based on the calculation of the relative abundance index (RAI) of each species in natural forest or core area, Porcupine (Hystrix brachyura) has the highest RAI compared to other species (with RAI = 3.41). Followed by Barking Deer (Muntiacus muntjak) with RAI = 2.17, Wild Boar (Sus scrofa) with RAI = 1.11, and Short-tailed Mongoose (Herpestes brachyurus) with $\mathrm{RAI}=0.04$. Whereas in the edge forest or ecotone area, Wild Boar (Sus scrofa) has the highest RAI compared to the other species with a value of RAI $=4.12$. Then, followed by Barking Deer (Muntiacus muntjak) with $\mathrm{RAI}=2.66$ and Malayan Tapir (Tapirus indicus) with a value of RAI $=0.04$.

\section{DISSGUSION}

Based on the data obtained, there are 22 species of medium-large terrestrial mammals in the core and ecotone areas. Those species of mammals are distributed within two study areas, but not all species distributed evenly. The diversity index (Shannon-Wiener Index) in each region obtained was $\mathrm{H}^{\prime}=2.2038$ for the core area and $\mathrm{H}^{\prime}=2.0541$ for the ecotone. From the categories determined by Odum (1983), the two regions fall into the category of moderate species diversity, which is in the range between 1.5 - 3. It also means that habitat features largely affect the presence of species found. While the results of the calculation of the richness index of the two regions obtained different values, in the ecotone area of 17.8262 and the core area of 17.8171 .

The results of this study found a similar with the study conducted by Idrus (2018) who obtained a value of $\mathrm{H}^{\prime}=2.15$ at the Way Canguk Research Center in Bukit Barisan Selatan National Park. The study of Kasayev et al. (2018) found $\mathrm{H}^{\prime}=2.06$ in swampy habitat in the Rimbo Panti Nature Reserve, West Sumatra. Santosa et al. (2008) also found that the diversity of mammals species in lowland and swamp habitats at the Pondok Ambung Research Station in Tanjung Puting National Park, Central Kalimantan, has a medium-value with $\mathrm{H}^{\prime}=2,179$. A karst area in East Kalimantan has a value of $\mathrm{H}^{\prime}=$ 2.38 (Kartono, 2015).

Diversity is identical to the stability of an ecosystem. When the diversity of an ecosystem is relatively high then the condition of that ecosystem tends to be stable (Odum, 1983; Fachrul, 2012). Indriyatno (2006) stated that the species diversity is high if the community is composed of many species with an abundance of the same species or almost the same species diversity, resulting in high complexity, because the interactions that occur within the community are very high.

Based on the species diversity of unequal test between core and ecotone area obtained $t_{\text {count }} 0.41365$ ( $\mathrm{p}<0.05)$. This result is different from the study conducted by Kartono (2015) which states that the three research sites, namely secondary forests, oil palm plantations and karst areas, have no real difference in diversity of mammals. However, Kartono (2015) in his research stated that the diversity index of mammal species in karst forest habitat has a greater value $\left(\mathrm{H}^{\prime}=2.38\right)$ compared to secondary forest and oil palm plantation.

Similarity index (E) in two areas, found that the value of 0.7106 for the ecotone area and 0.7625 for the core area, or for both areas the value is in the range between 0.7106 and 1 . This means that in the habitat there is individuals of a species still dominate the area but in small numbers. According to Santosa et al. (2008), similarity of species has an indicator value of $\mathrm{E}=1$. If the value of $\mathrm{E}=1$ means that in the habitat there are no species of mammals that dominate. While the Jaccard similarity Index (JI) 
scores 0.6363. Means that these values approach the similarities between communities. The dominance index value obtained in this study is 0.1758 for the ecotone area and the core area is 0.1719 . This means that in the two areas there was dominance with a low value.

Based on the research of Santosa et al., (2008) in lowland, desert/bush and swamp habitat at the Pondok Ambung Research Station, Tanjung Puting National Park in Central Kalimantan, it was found that the similarity index index was in the range of $0.8442-1$. While the community similarity value the highest is in the type of desert/ bush habitat with post-burnt habitat. In this study, although the location used is different from this study, it can be seen that there is a big possibility that the similarity of the location of the vegetation and its environment in the area, which are namely ecotone and core, affects the similarity and similarity of species found. In addition, the low species dominance in each region also affects the similarity of the species. This is in accordance with the statement of Magurran (2004) that the dominance of certain species and the unequal distribution of species causes the similarity of species to decrease. Low similarity (uneven) is caused by competition in utilizing available resources. This is also influenced by the availability of feed in the habitats that are occupied is one of the main factors for population presence.

Based on the calculation of the relative abundance index in the two areas, the values obtained were different either for each species of mammals as well as the areas. In the core area, Procupine (Hystrix brachyura) is a mammal that has the highest RAI value, followed by Barking Deer (Muntiacus muntjak), and Wild Boar (Sus scrofa). Whilst the Sumatran Tiger (Panthera tigris sumatrae), as the top predators in the region, has the position of $15^{\text {th }}$ rank of RAI with a value of 0.13 . Whereas in the ecotone area, Wild Boar (Sus scrofa) placed at the first rank, followed by Barking Deer (Muntiacus muntjak), and Porcupine (Hystrix brachyura). In ecotone area, Sumatran Tiger (Panthera tigris sumatrae) placed at $8^{\text {th }}$ rank with a RAI value of 0.18. Based on trophic level (based on the type of food) which is divided into three categories i.e. herbivores, carnivores and omnivores, the relative abundance of herbivores has a high value. Therefore, the pyramid of food web will be formed properly and the balance of the ecosystem in the research location will be occurred. This is in line with the study of
Santosa et al. (2008) which obtained 14 species of herbivores, five species of carnivores, and three species of omnivores.

\section{Conservation values of terrestrial mammals}

Based on the results of the study, there were 22 species of medium to large-sized terrestrial mammals. Among of those, 13 species are protected under the law of the Republic of Indonesia. In addition, two species are categorized as Critically Endangered (CR) and one species as Endangered (EN) according to IUCN's red list.

In species conservation efforts, the determination of umbrella species is very important because when an umbrella species is protected, the effort will also be protecting the other species (Choudhury, 2013). The establishment of umbrella species is expected to minimize the need for human resources and funding that is still low to support wildlife conservation (Kiffner et al., 2015). As a top predator, the Felids family can be used as an umbrella species in species conservation efforts in the area of Batutegi Protected Forest.

Based on the results of this study, the Felids were found in both areas of core and ecotone, namely Leopard Cat (Prionailurus bengalensis), Marbled Cat (Pardofelis marmorata), Asiatic Golden Cat (Pardofelis temminckii), and Sumatran Tiger (Panthera tigris sumatrae). Sumatran Tiger abundance core area (natural forest) is 0.13 while in the ecotone area is 0.18. The presence of tigers in the two regions is possible because of both areas are part of their home range, and prey species in both areas is also abundant. Many prey species of Sumatran Tiger in the area including birds, reptiles, amphibians, fish and invertebrates, but the main prey species are Wild Boar (Sus scrofa.), Sambar Deer (Cervus unicolor), Barking Deer (M. muntjak), Greater Mouse-deer (Tragulus napu.), Serow (Capricornis sumatraensis), and Malayan Tapir (Tapirus indicus) (Dinata and Sugardjito, 2008). Some other smaller mammals such as Porcupine (Hystrix brachyura) is an alternative prey species when ungulates difficult to hunt. Sumatran Tiger home range for adult females ranges from $40-70 \mathrm{~km}^{2}$ and adult males around $180 \mathrm{~km}^{2}$. The home range includes the home range of two adult females (Franklin et al., 1999; Griffith, 1994). The home range and abundance of tigers are also affected by the availability of prey species (Hutajulu, 2007). 
The total area of the Batutegi Protected Forest is 58,174 ha and the remaining around 10,000 ha is still natural forest, while the rest of area has been cultivated by the community in the social forestry scheme (KPHL Batutegi, 2012). In addition to the narrow natural forest area, this area is also not free from illegal human activities in the core area (natural). As found in this study, there is hunting activity in the core area. Poaching of tiger prey can result in reducing the tiger food, and this cause that the tigers to roam more extensively to the outside of the area, especially the core area. As a result, it can cause conflict between human and tigers. According to Hutajulu (2007) an effective conservation efforts require accurate information on population size in an area, geographical distribution of species, connectivity between areas, as well as ecological and biological aspects of species. This information is needed to find out suitable habitat, population size and threats to develop a short-term, medium-term and long-term conservation strategy in an area.

\section{GONGLUSIONS}

From the results of the research can be concluded that, using unequal test known that there is a significantly different on species diversity of terrestrial mammals between in natural forest (core) area and within forest edge (ecotone) area. There is not different significantly on species richness between core and ecotone areas. Species similarity is significantly different between in natural forest and in edge forest areas. In core area terrestrial mammals species are distributed evenly, while in ecotone area they are distributed less evenly. Value of species diversity is not significantly different either in core area and in ecotone. Both areas has moderate category in species diversity index. Value of dominance index is not significantly different in both study areas. Either in core and ecotone areas, there are three species that stay in highest rank of relative abundance index, i.e. Porcupine (Hystrix brachyura), Barking Deer (Muntiacus muntjak), and Wild Boar (Sus scrofa). There is not significantly different in the dominance of terrestrial mammals species between in natural forest and in ecotone. Both areas included into category of low in species dominance.

\section{AGKNOWLEDGMENTS}

RH would like to express his thank to Karmele L. Sanchez, Programme Director IAR Indonesia, who has given her fully support to this study. Thank to all IAR Indonesia field team for their invaluable assistance in collecting field data. A highly appreciation given to Bapak Ir. Y. Ruchyansyah, Head of KPHL Batutegi, for granting permission to conduct this research in the area.

\section{REFERENGES}

Alikodra, H.S. (2010). Pengelolaan Satwa Liar dalam Rangka Mempertahankan Keanekaragaman Hayati Indonesia. IPB Press, Bogor, Indonesia.

Alikodra, H.S. (2002). Pengelolaan Satwa. Jilid 1. Yayasan Penerbit Fakultas Kehutanan IPB, Bogor, Indonesia.

Ariyanto, T. (2007). Kelimpahan mamalia besar di kawasan hutan Sipurak dan sekitarnya, Taman Nasional Kerinci Seblat. BS thesis, Universitas Nasional, Jakarta, Indonesia.

Choudhury, A. (2013). The Mammals of North-East India. First ed. Gibbon Books and the Rhino Foundation for nature in NE India, Guwahati, India.

Dharmawan, A., Ibrohim, H., Suswono, H. and P. Susanto (2005). Ekologi Hewan. Penerbit Universitas Negeri Malang, Malang, Indonesia.

Dinata, Y. and J. Sugardjito (2008). Keberadaan harimau sumatera (Panthera tigris sumatrae Pocock, 1929) dan hewan mangsanya di berbagai tipe habitat hutan di Taman Nasional Kerinci Seblat, Sumatera. Biodiversitas 9(3):222-226

Fachrul, M.F. (2012). Metode Sampling Bioekologi. Bumi aksara, Jakarta, Indonesia.

Franklin, N., Bastoni, Sriyanto, Siswomartono, D., Manansang, J.D. and R. Tilson (1999). Last of the Indonesian tigers: a cause of optimism. In Riding the Tiger: Tiger Conservation in Human-dominated Landscape (eds J. Seidensticker, S. Christie \& P. Jackson), pp. 113-125. Cambridge University Press, Cambridge, UK. 
Griffiths, M. (1994). Population density of Sumatran tigers in the Gunung Leuser National Park. In Sumatran Tiger Population and Habitat Viability Analysis Report (eds R. Tilson, K. Soemarna, W. Ramono, S. Luslie, K.H. Taylor \& U. Seal), pp. 93-1-2. Indonesian Directorate of Forest Protection and Nature Conservation and IUCN/SSC Conservation Breeding Specialist Group Captive Breeding Specialist Group, Apple Valley, USA.

Huda, R., Anirudh, N.B., and K.L. Sanchez (2018). Diversity of carnivorous mammals in Batutegi Nature Reserve, Lampung, Sumatra. Journal of Indonesian Natural History 6(1): 37-45.

Hutajulu, M.B. (2007). Studi karekteristik harimau sumatera (Panthera tigris sumatrae, Pocock 1929) berdasarkan camera trap di lansekap Tesso Nilo-Bukit Tigapuluh, Riau. MSc thesis, Universitas Indonesia, Depok, Indonesia.

Idrus, N.I. (2018). Keragaman mamalia pada area kebakaran di Stasiun Pusat Penelitian dan Pelatihan Konservasi Way Canguk, Taman Nasional Bukit Barisan Selatan. MS thesis, Universitas Lampung, Bandar Lampung, Indonesia.

Indriyanto. (2006). Ekologi Hutan. PT. Bumi Aksara, Jakarta, Indonesia.

Kartono, A.P. (2015). Keragaman dan kelimpahan mamalia di perkebunan sawit PT Sukses Tani Nusasubur, Kalimantan Timur. Media Konservasi 20(2): 85-92.

Kartono, A.P., Gunawan and I.S. Maryanto (2009). Hubungan mamalia dengan jenis vegetasi di Taman Nasional Gunung Ciremai. Jurnal Biologi Indonesia 5(3): 279-294.

Kasayev, T., Nurdin, J., \& W. Novarino (2018). Keanekaragaman mamalia di Cagar Alam Rimbo Panti, Kabupaten Pasaman, Sumatera Barat. Furnal Biologi Unand 6(1): 23-29.

Kiffner, C., Peters, L., Stroming, A. and John Kioko (2015). Bushmeat consumption in the Tarangire-Manyara ecosystem, Tanzania. Tropical Conservation Science 8(2):318-332.

KPHL_Batutegi (2016). Kondisi umum KPHL Batutegi. http://kphlbatutegi. blogspot.com [Accessed 14 February 2019].
KPHL Batutegi (2012). Rencana pengelolaan jangka panjang KPHL Batutegi. Unpubl. document, Dinas Kehutanan, Bandar Lampung, Indonesia.

Magurran, A.E. (2004). Measuring Biological Diversity. Blackwell Publishing, Oxford, United Kingdom.

Odum, E.P. (1983). Basic Ecology: Fundamentals of Ecology. Holt-Saunders Publisher, Tokyo, Japan.

Prasetyo, L.B. (2017). Pendekatan Ekologi Lanskap untuk Konservasi Biodiversitas. Fakultas Kehutanan IPB, Bogor, Indonesia.

Sanderson, J. and G.M. Harris (2013). Automatic data organization, storage, and analysis of camera trap pictures. fournal of Indonesian Natural History 1(1):11-19.

Santosa, Y. (1995). Teknik Pengukuran Keanekaragaman Satwaliar. Fakultas Kehutanan IPB, Bogor, Indonesia.

Santosa Y., Ramadhan, E.P. and D.A. Rahman (2008). Studi keanekaragaman mamalia pada beberapa tipe habitat di Stasiun Penelitian Pondok Ambung Taman Nasional Tanjung Putting Kalimantan Tengah. Media Konservasi 13(3): 1-7.

Shancez, K.L., Grey, M., Martin, T.L., Gracia, I.M., Ortuza, G., Miguel, R.J., Rasidin, V. and W. Supriatna (2010). A Study Into the biology, physical geography and human activities of the Batutegi Nature Reserve (Lampung, sumatera, indonesia). Unpubl. report. Kerjasama Program Eko2pass, Aecid, Ministerio de Asuntos Exterioeres de Cooperation dan Yayasan IAR Indonesia, Bogor, Indonesia.

Whitten, T., Damanik, S.J., Anwar, J. and N. Hisyam (2000). The Ecology of Sumatra. Periplus Editions (HK) Ltd, Singapore.

Widjaja, E.A., Maryanto, I., Wowor.D, S.N. Prijono (2011). Status Keaneka-ragaman Hayati Indonesia. LIPI Press, Jakarta, Indonesia. 